\title{
Cross-Cultural Effects on the Budgeting Cycle: The Impact of Power Distance on Participation, Voice, and Explanation in the Libyan Oil Sector
}

\author{
Ramadan E. Kanan \\ Al Buraimi University College, Oman \\ Department of Business Administration and Accounting \\ Oman \\ Kieran James \\ University of the West of Scotland \\ Scotland and University of Fiji \\ Fiji Islands \\ Joseph M. Mula \\ University of Southern Queensland \\ Australia
}

\begin{abstract}
Globalization is causing the rapid integration of markets, nations, and technology, which facilitates faster contact between people, corporations, and nations. However, there is a failure to notice cultural differences that exist between workforces across nations. Therefore, all employees need to have cultural sensitivity, which could be helped by studying cross-cultural differences. Current understanding of how and why differences in budgeting processes can be attributed to cultural differences is important. In this context, cultural influence on budgeting processes has been extensively researched in manufacturing and service industries but has been rarely studied in relation to the culturally diverse oil and gas industry. This study utilizes the societal cultural dimension "power distance" identified by Hofstede to identify differences in budgeting processes in terms of participation, voice, and explanation between Libyan and Anglo-American companies operating in the Libyan oil sector. Results indicate that there are significant differences between Libyan and Anglo-American companies. However, Libyan workers in Libyan companies do not significantly differ from Libyan workers in Anglo-American companies. Libyan workers tend to maintain their own culture when it comes to participation, voice and explanation.
\end{abstract}

Keywords: Arab culture; Culture; Hofstede; North Africa; North African culture; power distance; budget; budgeting process; Libya; Libyan oil sector

\section{Introduction}

As a consequence of globalization, there has been considerable research interest in understanding the impact of culture on the business environment (Douglas et al. 2007, Honold 2000). Hofstede (1983, p. 75) states that "[t]wenty or even 10 years ago, the existence of a relationship between management and national cultures was far from obvious to many, and it may not be obvious to everyone even now". Garrison, Noreen and Brewer (2006) identified that there have been tremendous changes in the business environment over the last two decades. Furthermore, in the past two decades, there have been considerable concerns about the influence of culture on many aspects of an organization. These concerns are typically on account of changes in the business environment and the variety of organizations and workplaces (Erez, 1994 as cited in Aycan 2000, Miroshnik 2002). Weijermars, de Jong and van der Kooi (2008, p. 19) argue that "[m]odern business management must address cultural diversity and requires trans-cultural competence, using communication, empathy and creativity". There are many challenges facing multinational companies in which foreign subsidiaries operate globally, including the important impact of heterogeneous cultural, institutional, and organizational contexts. When individuals join an organization or institution they carry with them their beliefs, values, attitudes, norms, conflicting feelings, traditions, prejudices, and cultures. They have different thoughts and attitudes with respect to the same management practices (Tsui 2001). Each environment has a different culture which requires different managerial behaviours. What is appropriate to a certain culture may not be appropriate for another (Miroshnik 2002). 
Ball et al. (2008, p. 143) argue that "[e]very culture has a set of attitudes and beliefs that influence[s] nearly all aspects of human behaviour and help[s] bring order to a society and its individuals". These will influence, underlie, and shape managers' and employees' ways of behaviour, thought, recognition, perception, expectation, and understanding of various circumstances and events related to work and others (Griffin \& Pustay 2010, Prabhu 2005, Sengupta \& Sinha 2005, Weijermars, de Jong \& van der Kooi 2008). Understanding individuals' attitudes, beliefs, values, norms, and cultures is of paramount importance. It facilitates and enables managers dealing with different individuals of various cultures to know why they behave in a certain way or as they do, to maintain high morale and to motivate individuals to achieve an organization's goals. It also enhances the efficiency of business processes especially in multinational companies where the diversity of the workforce is expected to be pervasive (Mendonca \& Kanungo 1996). Managers responsible for these companies' local operations should adapt practices according to localized conditions. This is critical in terms of maintaining their legitimacy and acceptance as perceived by local stakeholders (Sauers et al. 2009). Recently, researchers have acknowledged that managers only see national differences between overseas customers as significant but they do not consider this with respect to people within their own businesses (Miroshnik 2002). Recognizing cultural differences is important for managing international corporations and disregarding these differences is unproductive and short-sighted leading to the marginalization of talent in multinational corporations (Miroshnik 2002, Radebaugh, Gray \& Arpan 1997).

When communication occurs across cultural boundaries, managers should learn verbal and nonverbal language when communicating with people to avoid miscommunication and misunderstanding. This is because both senders and receivers encode and decode information when they communicate by using different cultural filters (Griffin \& Pustay 2010, Zaharna 1995). Some hand gestures and facial expressions can have two or more meanings in two different cultures. For example, a person nodding her/his head in the USA means that she/he agrees whereas it means that she/he disagrees in Bulgaria (Griffin \& Pustay 2010). Time also fosters different attitudes from culture to culture; for example, in Anglo-Saxon cultures time is money and people expect meetings to start on time. In an Arabic culture meetings may start later than the arranged time because they may be interrupted by family or friends. Managers who work in multinational companies should note any cultural differences between countries. For example, Muslim people consider religion as an important part of their lives and businesses. In south Russia fortune telling and ghosts are crucial elements in peoples' lives. Seventy-three years of communist rule was not able to nullify the power of such beliefs. Therefore, understanding these differences can help managers to deal with cultural variances (Miroshnik 2002). Douglas et al. (2007) identify differences in behaviour between Egyptian and American employees and argue that their findings support the notion that management behaviour is embedded in culture.

Multinational companies usually bring into the host country some positive changes such as their management practices and technology and introduction of new products and services. They can also exert a major influence on the culture and raise local standards of living. As a result, people in the host cultures develop new norms, standards, and behaviours, especially in developing countries (Griffin \& Pustay 2010, Sauers et al. 2009). On the other hand, Jain and Verma (1996) argue that there are some changes that are not positive. Cultural differences can lead to increased costs through communication breakdowns, high turnover rates, and interpersonal conflicts.

Arab countries' and Anglo-American countries' management methods are different in style and orientation. Arab managers generally follow and obey rules, regulations and customs instead of exercising their own professional judgments, particularly under authoritarian regimes (Atiyyah 1993). Ali (1990) finds that in Arab management, obedience and submissiveness are rewarded while creativity and original thinking are not always warmly received. Yasin and Stahl (1990) attribute this to the lack of democracy in Arab culture, media control by governments, and non-existence of free elections. All of these lead individuals to a feeling of institutional powerlessness. Bjerke and Al-Meer (1993, p. 30) state that "as in other nations, Arab managers do not exist in an economic or social vacuum. They are heavily influenced by society's social structure and by the values, norms and expectations of its people". In Arab countries, family and friendship are significant aspects in the operation of foundations and groups (Bjerke \& Al-Meer 1993). Yasin and Stahl (1990) argue that Arab culture is traditional and relationship-oriented because of influences from family and religion. Thus, Arab managerial motivational effectiveness reveals different patterns of managerial motivational effectiveness compared to Anglo-American culture, which is power and achievement oriented. On the other hand, Western managers' loyalties and obedience are driven by their professional judgments regarding profitability and personal financial rewards. Individualism and the Protestant work ethic are the basis for high achievement in Western societies (Ali 1993, Weber 1965, Yee et al. 2008). Employees and their organizations do not operate in isolation from their societal environment (Tayeb 1997). 
The interaction between workers and supervisors occurs in the workplace. In this context different preferences will manifest themselves in the workplace, especially where different cultures come together in organizations that operate internationally (Bing 2004). This is especially so for those whose workplaces are culturally diverse. This is particularly the case in relation to activities involving social relations (Marx's "relations of production"), especially with respect to budgeting. Milani (1975) argues that human aspects are of paramount importance to budgeting because a budget does not exist without people. Budgets are prepared, controlled, and revised by people to facilitate management's functions. In this regard budgets and budgeting are influenced by employees' behaviours (Milani 1975). Budgetary processes are one of the most important aspects that multinational corporations need to pay attention to because these appear to be critical to an organization's success. For example, Ueno and Sekaran (1992) find that USA companies working in Japan, and Japanese companies working in USA have difficulties in effectively dealing with cultural diversity and practices in each location. Paláu (2001) also argues that the most influential obstacle that prevents harmonization in organization budgeting is often related to culture or, more specifically, to cultural differences. This situation is common in the extractive industries, most notably oil and gas. Recently there has been an increase in energy demand especially for oil and gas, which has increased search for and production of oil and gas by multinational corporations. Therefore, multinational companies operating in the oil industry encounter formidable managerial challenges that stem from a multicultural workforce. The challenges of these cultural differences are far from obvious or new to such companies. However, globalization has intensified them (Weijermars, de Jong \& van der Kooi 2008).

Pre-requisite understanding of the Anglo cluster countries is required to understand international relations and trade around the world. This understanding is also important for this study in terms of its comparison between Anglo-American and Libyan companies operating in the Libyan oil sector. Anglo-American countries serve as the headquarters for many of the world's largest multinational companies. They represent many of the most economically advanced countries and most developed in the contemporary world. Anglo-American countries represent only $7 \%$ of the world's population but account for $25 \%$ of world trade, and $40 \%$ of the world's Gross National Product (Ashkanasy, Trevor-Roberts \& Earnshaw 2002). Cultural values of the English have spread across the world, and now the Anglo cluster encompasses some of the most advanced and robust democratic economies in the developed world. This cluster strongly endorses accomplishment especially in the chase for material wealth. It also reflects a male dominated society in practice. There are distinct differences between countries in this cluster despite their similarities. South Africa and New Zealand stand out in this respect (Ashkanasy, Trevor-Roberts \& Earnshaw 2002). Ronen and Shenkar (1985) argue that geography is more important when talking about cultural clusters because culture spreads first to the nearest area "birthplace". They justify the Anglo-American cluster which contains countries from different continents, because of colonization and immigration. Language is also shared between Anglo-American countries where people speak English. Gupta, Hanges and Dorfman (2002) conclude that there are three factors involved in classifying countries: (a) mass migrations and ethnic social capital; (b) geographic nearness; (c) and spiritual and linguistic commonality. Anglo clusters are countries that speak English such as United States, Canada, United Kingdom, the Irish Republic, Australia, New Zealand, and to a certain extent South Africa. These countries are all predominantly Anglo-Saxon, developed nations, and were all colonized by Britain (Ashkanasy, Trevor-Roberts \& Earnshaw 2002).

Arabic clusters include countries that speak Arabic, for example, Syria, Libya, Bahrain, United Arab Emirates, Kuwait, Oman, Morocco, Egypt, and Saudi Arabia. Islamic, European, and Ottoman Empire influences all played important roles in creating commonalities in socio-cultural values and practices. Ali (1990) argues that there are many historical factors which have influenced Arab culture and its management practices such as the legacy of colonial bureaucracies and Ottoman Empire as well as European, tribal and family traditions; Islamic influence; Western nations' influence in recent decades; political constraints; and governmental intervention. Arabic countries have many commonalities, sharing the same language, religion and socio-cultural characteristics (Kabasakal \& Bodur 2002, Twati 2007). Kabasakal and Bodur (2002, p. 44) argue that "the Koran has been a unifying force that strongly influences societal practices and acts as a driver towards creating a common culture in the Arabic cluster".

\section{Libyan context}

Libya is situated in North Africa and has extensive reserves of oil and gas. Its dominant culture is Arabic. Despite its tremendous importance in both developed and developing countries, the oil industry has not been studied to the same extent as the manufacturing and service sectors, particularly in terms of cultural differences. 
Skarlicki (2001) confirms that the study of cross-cultural differences has been largely restricted to the manufacturing sector. Furthermore, as the number of multinational employees increases, senders and receivers of information in companies that operate in the oil sector require special techniques to convey information accurately especially where cultural differences may hinder communication and reception (Weijermars, 2008).

Until the discovery of oil in 1951, Libya's history was marked by severe levels of poverty. Despite the discovery, beneficial effects were slow to develop due to a lack of production and exports. This was primarily caused by a shortage of capital and expertise in management and accounting fields. The latter was caused, in part, by academic underdevelopment in the country (Clarke 1963). There were just sixteen students who graduated from universities in 1949, and no citizen in the country had a PhD (Abouzied 2005, Gurney 1996). The industrial sector was undeveloped and there was a scarcity of capital and skills.

Oil revenues contribute to the bulk of Gross National Products (GNP) of oil producing countries. Similarly, the oil sector plays an important role in Libya since its economy is heavily dependent on oil revenues which represent more than 90 percent of GNP (Yahia 2008). The majority of Anglo-American oil companies disinvested from Libya after sanctions were imposed in 1992 by the United Nations (UN) and USA. In 2003 the UN lifted sanctions which resulted in an increase in foreign investment in the oil sector and the re-investment by AngloAmerican companies which were granted concessions (Otman 2008). This development has necessitated a better understanding of how cultural differences affect operations in general and budgeting in particular. According to Hofstede's cultural dimensions, there are differences between the two cultures Arabic and Anglo-American. Despite the criticism of Hofstede's model, it is still regarded as the most prominent, comprehensive, robust, wellknown, influential, and pioneering model among cross-cultural researchers and Hofstede is the most often cited author in culture research (Harris and Carr 2008; Fang 2009; Jansen, Merchant et al. 2009).

Anglo-American countries and Libya are culturally different in many respects, including religion, predominant ethnic groups, language, political and economic systems, traditions, attitudes, and external environments. In intercultural studies, there is a tendency to view Anglo-American and Arab cultures as dialectical cultural opposites (Yasin \& Stahl 1990, Zaharna 1995). Employees working in these companies have different languages, education systems, management styles, backgrounds, and values. According to Hofstede (2001), workers from different cultures behave differently in managing their businesses including budgets. Hofstede (1991) also notes that culture impacts person's views on many topics, including significantly, budgeting behaviour.

\section{Research question}

It is generally assumed that both Libyan and Anglo-American companies prepare their budgets with similar goals in mind, i.e. to achieve their business goals (Bart 1988). However, it is not clear that companies operating in the Libyan oil sector do in fact follow similar procedures and techniques in developing their budgets and in their budgeting processes. Therefore, the research question that arises in this study is: "how and to what extent does power distance affect participation, voice, and explanation in the budgeting processes undertaken by Libyan and Anglo-American companies operating in the Libyan oil sector"?

This study assesses the current understanding of how and to what extent participation, voice and explanation can be attributed to cultural dimension. The study uses the societal cultural dimension of power distance, identified by Hofstede (2005), in an endeavour to determine differences between local and Anglo-American companies operating in the Libyan oil and gas industry. It identifies the differences between Anglo-American and Libyan companies in their budgeting processes and explains to what extent they are different. Prior studies (Bailes \& Asada 1991, Douglas et al. 2007, Ueno \& Sekaran 1992) tend to stop at descriptions of cross-country differences in budgeting practices (Yee et al. 2008). By contrast, this study goes one step further by explaining observed differences in terms of cultural theory.

\section{Hofstede's (2005) model}

Hofstede's model is regarded as the most prominent, comprehensive, robust, well-known, influential, and pioneering model among cross-cultural studies. His work also represents a considerable improvement in understanding of differences between countries according to their cultural contexts (Drogendijk \& Slangen 2006, Fang 2009, Harris \& Chris 2008, Jansen, Merchant \& Van der Stede 2009, Radebaugh, Gray \& Black 2006, Robbins et al. 2008, Silvia 2006, Soares, Farhangmehr \& Shoham 2007, Twati 2007, Yee et al. 2008). 
His study is revolutionary in the domain of cultural differences among countries and the most prominent work in the related fields of cross-cultural business communication, accounting and management (Dwyer, Mesak \& Hsu 2005, Fang 2006, Silvia 2006, Soares, Farhangmehr \& Shoham 2007, Taylor 2000, Twati 2007).

However, Hofstede's model has not remained immune from criticism. Several scholars have increasingly criticized the model in recent years (Baskerville 2003, Hampden-Turner \& Trompenaars 1997, McSweeney 2002a, 2002b, Schwartz 1994, Smith 2002, Williamson 2002). Criticism of Hofstede's model is acknowledged as wellfounded by many researchers, and by Hofstede himself, though many researchers still use his model (Silvia 2006, Twati 2007). Baskerville (2003) argues that numerous research studies have used Hofstede's quantification and classification of cultural differences in the accounting discipline. The importance of using Hofstede's model is that it can be the basis for other comparative studies of accounting generally and of the budgeting process in particular. Because of its popularity, robustness, and simplicity of application it enables academics and practitioners to gain a better understanding of the phenomenon of cross-cultural difference (Yates \& Cutler 1996).

The simplicity of Hofstede's (2001) model is one of the reasons why the present researchers chose to utilize it. Moreover, his dimensions are uncomplicated, straightforward, and naturally interesting to both business readers and academic researchers across many disciplines (Chapman 1996). Furthermore, for cross-cultural comparative purposes, Hofstede's dimensions are well positioned for comparative studies (Dwyer, Mesak \& Hsu 2005, Osland \& Bird 2000, Twati 2007). Fang (2009, p. 4) also states that " $[t]$ he fact that not only academics but also managers can talk about culture-related management issues in terms of Hofstede's cultural dimensions is indicative of Hofstede's great influence". Furthermore, Hofstede's dimensions have been widely accepted and repeatedly validated over time (Christie et al. 2003, Sondergaard 1994).

In addition, this model is helpful in comparative cross-cultural studies or formulating hypotheses (Soares, Farhangmehr \& Shoham 2007). Hofstede's four dimensions have scores for Arabic countries in general, and for Libya in particular as well as for Anglo-American countries (USA, UK, Canada, and Australia) which aids the comparisons. Another reason for choosing Hofstede's model is that many authors have used Hofstede's model to study the influence of culture on budgeting processes (Douglas et al. 2007, Douglas \& Wier 2005, Ueno \& Wu 1993, Yee et al. 2008).

\section{Culture}

Culture is a readily understandable word. However, it is difficult to define clearly. Although the word culture appears in everyday usage of language, it is still used loosely to express many different concepts (Dahl 2004, Spencer-Oatey 2008). Because of the wide influence of culture on most human behaviour, it is difficult to define culture (Soares, Farhangmehr \& Shoham 2007). Formal culture incorporates the economic systems, attitudes, education systems, laws and legal systems, social rules, associations, enterprises, religious communities, school systems, family structures, habits, art, values, beliefs, morals, ritual practices, ceremonies, and forms. Informal culture includes stories, rituals of daily life, gossip and language, customs, habits, resultant behaviour, norms, and artefacts shared by a certain society. These norms govern how people act, how they define themselves, and how they differ from other societies' members. They also govern how these shared elements facilitate communication with each other in effective and efficient ways. Moreover, they influence a particular group of people's behaviours and their mental lives (Bradford 2005, Christie et al. 2003, Dahl 2004, Hofstede \& Hofstede 2005, Jennergren 1980, Swidler 1986, Twati 2007, Williams 1988).

\section{Power Distance}

Power distance (PD) deals with the level of inequality in society and how people handle the fact that members of the society are unequal. In many societies, laws have been conceived to maintain equality between members of societies (Hofstede \& Hofstede 2005). Hofstede and Hofstede (2005, p. 46) defined PD as "the extent to which the less powerful members of institutions and organizations within a country expect and accept that power is distributed unequally". Family, school, and community are the basic elements of a society while the places where people work are labelled as organizations (Hofstede \& Hofstede 2005). PD refers to the distribution of power at different levels of organizations in different societies. PD is also reflected in the hierarchical organization of companies, the admiration that is expected to be shown from inferior to superior, the political structures of centralization and decentralization, and by the faith in society that differences among its members must be decreased or that they are wanted and desired (Dahl 2004). 
However, a review of the literature revealed no studies in the accounting literature that have examined the effects of culture on budgeting processes in Anglo-American and Arabic cultural contexts and particularly in the Libyan context. Research has investigated the impact of national cultural diversity on budget practices in Asia, America and Europe (Lau \& Buckland 2000). By contrast, Arab and African countries have been overlooked. Libya is the largest African supplier of crude oil and gas to Western countries so it is fitting to study the effect of culture on budgeting within this industry in Libya (Al-Hengari, El-Bousiffi \& El-Moudir 2007, Hafner 2002).

\section{Budgetary Participation}

Participation in budgeting should include all managerial levels to achieve a fair budget and a fair process. If this is the case, managers will be positive towards budgets and they will work harder to achieve their budgets (Chong \& Chong 2002, Hofstede 1968). If not, it will lead to discouragement and create resentment between managerial levels (Weygandt, Kimmel \& Kieso 2001). Participation in the budgeting process is very important and researchers must start with theories about participation in decision-making (Hofstede 1968). Dundon et al. (2004) point out that participation could lead to a beneficial impact on work quality and productivity. Moreover, participation by lower level managers in decisions yields more practical plans because of open discussions and also provides motivational effects and improvement in the quality of decisions made (Chenhall \& Brownell 1988, Merchant, Chow \& Wu 1995, Pasewark \& Welker 1990). Milani (1975) states that participation is when employees can choose their own course of action. Participative budgeting is used by superiors to obtain information to reduce uncertainty about superiors' tasks and task environments (Chenhall \& Brownell 1988, Shields \& Shields 1998).

Participation might take place in procedures of planning and performance evaluation of the budget cycle (O'Connor 1995). In this regard, face to face participation between subordinates and superiors to establish a budget instead of imposing a budget on subordinates is essential for its sufficiency (Horngren, Sundem \& Stratton 2005, Licata, Strawser \& Welker 1986). Employees are expected to favour high budgetary participation when budget emphasis is high. Lau and Buckland (2000, p. 39) point out that "a compatible combination of high budget emphasis and high budgetary participation is likely to be associated with higher managerial performance than other combinations of budget emphasis and budgetary participation". Consequently, goal congruence is likely to be achieved when managers' goals comply with organizations' goals resulting in higher levels of performance (Mowen \& Hansen 2006, p. 329). This might be achieved when multinational companies' managers comprehend and take into consideration cultural diversity. However, budgeting processes and participation will vary from culture to culture due to cultural differences (Frucot \& Shearon 1991). Therefore the influence of culture on decision makers' behaviour has become a very important topic in the last decade (Soares, Farhangmehr \& Shoham 2007). Lau and Tan (1998, p. 168) also state that "national culture is likely to have an impact on the subordinates' reactions to budgetary participation". Consequently, Hofstede's dimensions are potentially relevant to participative budgeting issues (Frucot \& Shearon 1991). Douglas and Wier (2005, p. 163) also state that "Hofstede's Power Distance and Individualism are expected to influence organizational choices in budgetary system design".

Douglas and Wier (2005) argue that subordinates in low power distance cultures are involved in planning and decision making (Douglas \& Wier 2005, O'Connor 1995). In low power distance cultures, inferiors see their superiors as equal and employees expect their superiors to consult them and vice versa. Therefore, the expectations about participation are likely to be high (Frucot \& Shearon 1991, Tsui 2001). For example, US managers participate more in budgeting processes and the return on investment is regarded as a significant budget goal (Horngren, Foster \& Datar 1996, p. 188, Yee et al. 2008).

In high power distance cultures employees see their superiors as autocratic and do not expect to be consulted. Therefore, expectations of participation by employees in budgeting are not expected to be high in such cultures. Decisions are expected to be made by superiors without seeking their subordinates' participation (Frucot \& Shearon 1991, O'Connor 1995, Tsui 2001). Kabasakal and Bodur (2002) argue that in Arabic culture, family members are expected to obey the directions and decisions of the father without enquiries. Such norms and values created in a family are extended to society and encourage inequality of power distribution. In such cultures, Arora (1992) suggests that "[t]o increase the participation potential the system has to have a systematic, strong, legal foundation so that the people in power may be able to exercise only limited discretion". Creating a sociable working environment and increases in training and levels of education also help to increase the level of participation (Arora 1992). 
Subordinates know more about their task environment than their superiors do (information asymmetry). Participative budgeting is used by superiors to obtain information to reduce uncertainty about superiors' tasks and task environments (Shields \& Shields 1998).

According to Hofstede's (2005) model, Arab countries are classified as high PD. This means that participation between managers and employees will be expected to be less. Budgets will be imposed on employees from top levels without seeking subordinates' participation (Bjerke \& Al-Meer 1993, Chong \& Chong 2002, Douglas \& Wier 2005, Harrison 1992, Hofstede 1968, Hofstede \& Hofstede 2005, Lau \& Buckland 2000, Lau \& Tan 1998, Milani 1975, O'Connor 1995, Shields \& Shields 1998, Tsui 2001). On the other hand, Anglo-American countries are classified as low PD. This means that managers seek their subordinates' participation in the budgeting process and give them the opportunity to express their ideas and thoughts. To identify if there are differences between Libyan and Anglo-American companies we test Hypothesis 1 which is stated as follows: Hypothesis 1: Participation of employees in the preparation of budgets is higher in Anglo-American companies than in Libyan companies.

\section{Voice and Explanation}

Allocating resources of organizations is usually pressured by the scarcity of management resources and conflicts over goals. Budgetary requests cannot all be met when organizations operate with scarce resources. Therefore, fairness appears salient in these cases (Libby 1999, Wentzel 2002). Therefore, management is obligated to prioritize its goals which results in the reallocation of limited resources to those units considered to be at the top of management's priority list (Libby 1999). In this case, final decisions are made by superiors without the involvement of subordinates. This will lead to pseudo-participation because subordinates' perceptions are that their views have not been taken into consideration and therefore have not influenced the final budget. In this regard management should avoid these perceptions of 'pseudo-participation' by providing subordinates with a voice and giving them adequate explanations about any lack of influence and input in the final budget (Libby 1999).

Pseudo-participation is the term used to describe the act of top management when seeking only surface participation from subordinates, thus assuming entire control over the budgeting process. Pseudo-participation also is defined as the process that makes subordinates believe that they will have some influence on the budget that is set, despite the fact that their efforts are unobserved and neglected (Byrne \& Damon 2008, Libby 1999). Participation will not be realized or materialized because top management does not aim to consult subordinates (Lindquist 1995, Mowen \& Hansen 2006). Lindquist (1995, p. 123) states that "[i]n fact, some research has even suggested that anything less than full decision-control of budgets is pseudo-participation". He also states (1995, p. 124) that "the highest participation employees are permitted to make their own decisions (decision-control)". On the other hand, if managers and employees have input into budgets, and can appeal decisions that are made, this will ensure that a budget is based on accurate information and will enhance fairness of the budgetary procedure (Magner et al. 2006). Wentzel (2002) also points out that perceptions of fairness will be enhanced when participation during budgeting is increased. The commitment of managers to budgetary goals will also be enhanced and better performance will ensue.

Libby (1999) finds that employees who articulate their voice and receive an explanation perform better than those who have just a voice or an explanation or no voice and no explanation. Byrne and Damon's (2008, p. 208) results support Libby's study. They state that the results "reinforce the importance of an explanation and also show support for the pseudo-participation phenomenon-than an uninfluential voice, despite receiving an explanation, negatively affects performance". They also point out that the type of explanation is more important than simply giving an explanation. This affects performance and perceptions of fairness. In this regard, there is a positive relationship between perceived fairness and performance and the adequate explanation is the positive effect that voice has on performance (Byrne \& Damon 2008).

Voice has influential effects on people's lives and also has positive effects on decision making (De Cremer, Cornelis \& Van Hiel 2008, Lind, Kanfer \& Earley 1990, Lindquist 1995, Magner et al. 2006). Fuller et al. (2007) concur that voice is a very important tool for organizational success for a number of reasons. Voice allows the opportunity for constructive discussion essential for innovation process and also improves performance and competence. In the Soviet Union in the 1980s Mikhail Gorbachev famously introduced the terms glasnost (openness) and perestroika (restructuring); both are essential and work together. Brockner et al. (2001) and Klammer (1997) argue that voice is one of the determinants of procedural justice. 
Klammer (1997) argues that voice procedures, regardless of the decision outcomes, allow people to express their opinions and do contribute to the perception of fairness. When conducting the budgeting process, management should consider two elements: voice and explanation. There has been increasing interest in the notion of employee voice and its effects on organizational performance (Dundon et al. 2004, Lindquist 1995, Van Dyne, Soon \& Botero 2003). Klammer (1997, p. 5) states that "[w] hen people speak up and offer suggestions for improvement, it increases the likelihood that an organization will take steps necessary toward developing and improving itself". It is very important for managers to understand that there are strong effects of voice on diversity of human responses and managerial issues (De Cremer, Cornelis \& Van Hiel 2008, De Cremer \& Stouten 2005, Van Dyne, Soon \& Botero 2003). The reason is that when people receive unfavourable outcomes but they have been allowed voice the voice allowed increases their perception of fairness. They feel that they are valued and treated with respect and dignity which enhances self-esteem (Lindquist 1995, Magner et al. 2006, Tata 2005).

Explanation means communicating to subordinates justifications and reasons for arriving at decisions made including why particular feedback and inputs have not influenced and/or between incorporated into the final budget (Byrne \& Damon 2008, Libby 1999). Magner et al. (2006, p. 411) argue that "[b]udgetary decision makers should provide managers with clear, timely, and adequate explanations of the reasons for their budgetary decisions". Ceterus paribus any perceptions of unfairness are reduced by allowing employees voice and giving them explanations (Horvath, Ryan \& Stierwalt 2000, Renard \& Eastwood 2003). Furthermore, managers should be provided with sufficient and satisfactory explanations for the decisions made in relation to the budget while personal biases should be suppressed (Magner et al. 2006). Libby (1999) argues that when voice and explanation are included in the budgeting process subordinates consider the budgeting process as fair and this can lead to better performance.

These elements may differ from one culture to another. Managers should consider these elements in order to treat employees fairly. This will lead to more productivity, better performance, and higher satisfaction for employees. Such elements motivate employees because they feel that they are treated with respect and dignity (Horvath, Ryan \& Stierwalt 2000, Libby 1999). If this is not the case, it might lead employees to be less satisfied, less productive and less loyal to an organization (Byrne \& Damon 2008).

Cross-cultural studies indicate that differences exist between cultures in terms of perceptions of procedural justice (Klammer 1997). In particular, adequate voice and explanation, which are key parts of procedural fairness, may be perceived differently across cultures (Magner et al. 2006, Yee et al. 2008). Voice and explanation have an influential impact on performance, commitment to an organization and employees' attitudes and behaviours towards organizations (Byrne \& Damon 2008, Libby 1999). Lindquist (1995) also points out that allowing employees to participate in budgeting will increase employees' satisfaction with budgets, performance, and job satisfaction.

Galang (1999) studied voice and choice in the workplace to relation to power distance. He argues that understanding and taking into consideration cultural differences and how such differences influence social behaviour will prove beneficial especially when operating internationally. Kim and Leung (2007) support the argument that employees in collectivism and high power distance societies react against unfair treatment from authorities less negatively.

In the same vein, power distance influences procedural justice perception. High power distance cultures demonstrate a preference for more autocratic processes compared to cultures with low power distance (Klammer 1997). Clearly people from different cultures may have different opinions as to what constitutes effective and acceptable voice and explanation. Yee et al. (2008, p. 876) argue that "the concept of fairness and the very act of perception itself most likely vary significantly from culture to culture". Individuals may react differently to explanations due to individual diversity (Horvath, Ryan \& Stierwalt 2000). Culture has the role of shaping organizational and individual values, a discipline ignored by much prior research (Douglas \& Wier 2005). Horvath, Ryan and Stierwalt (2000) indicate that race and gender might interact in explanation of perceptions. They advocate for future studies to explore the impact that culture has on voice and explanation.

Despite the fact that voice and explanation have been studied to a certain extent in terms of cross-cultural differences and decision making, in relation to budgeting processes voice and explanation appear neglected in regard to the extent they might be influenced by cultural differences. 
Previous literature reviews indicate that none of the earlier studies (Brockner et al. 2001, Byrne \& Damon 2008, Detert \& Burris 2007, Horvath, Ryan \& Stierwalt 2000, Libby 1999, 2001, Tangirala \& Ramanujam 2008) have attempted to empirically address how culture influences perceptions of the effectiveness of voice and explanation in the budgeting process. Cross-cultural studies enhance the understanding of managers working in workplaces that are culturally different regarding principles of justice and fairness in various cultures (Kim \& Leung 2007).

Although in a individualistic culture managers seek their subordinates' involvement in decision making they still retain the authority for decision making and they may show a strong propensity for counselling and a pseudoconsultative style (Ali 1993). An executive from a culture that values silence and intuition may lead an employee from a culture that values frank and direct communication to believe that there has been true participation when there has really only been pseudo-participation (Yee et al. 2008). Thus, voice might have different effects according to cultural diversity (Brockner et al. 2001). De Cremer, Cornelis and Van Hiel (2008, p. 65) argue that "[p]rocedural fairness depends on how people interpret the situation, and such interpretations may vary as a function of individual difference variables". Anglo-American countries are classified as low PD. This means that managers seek their subordinates' participation in the budgeting process and give them the opportunity to express their ideas and thoughts. Furthermore, managers may give their employees more explanations about the differences in budgets. Voice and explanation may be different in Libyan and Anglo-American companies (Ali 1993, Harrison et al. 1994, Hofstede 2001, Libby 1999, Magner et al. 2006, Magner, Welker \& Campbell 1995, Miroshnik 2002, Yee et al. 2008). To identify if there were significant differences between Libyan and AngloAmerican companies Hypothesis 2 and 3 were tested: Hypothesis 2: Employees in Anglo-American companies will have more voice and say in the budgeting process than those in Libyan companies.

Hypothesis 3: Employees in Anglo-American companies will receive more explanation about the changes in their budgets than those in Libyan companies.

\section{Research Method}

Surveys were distributed to all managerial levels in Libyan and Anglo-American companies operating in the Libyan oil sector. The questionnaire in this study (reproduced as Appendix A) was designed to solicit information about budgets and budgeting processes in order to identify differences between both cultures in term of participation, voice, and explanation and how power distance affects budgets and budgeting processes. Participation, voice, and explanation were measured by asking respondents (Libyan and Anglo-American employees) to assess the extent of agreement or disagreement with the items in the close-ended questionnaires. Their agreements or disagreements were measured through a 5-point numerical Likert-type scale. In instruments measuring attitudes, beliefs, and opinions a Likert scale is often utilized because of its usefulness (DeVellis 2003). All scales ranged from $1=$ strongly disagree to $5=$ strongly agree. This is the easiest scale to construct and generally chosen by individuals although it is difficult to judge the meaning of a single score (Zikmund 2000). The questionnaire was created in English and then was translated into the Arabic language. The survey were conducted in both English and Arabic languages. For Libyan companies most employees speak Arabic.

\section{Data analysis}

Nine items were used for participation as adapted from previous studies (Harrison et al. 1994, Leach-L $\tilde{A}^{3}$ pez, Stammerjohan \& McNair 2007, Magner, Welker \& Campbell 1995, Maiga \& Jacobs 2007, Milani 1975, O'Connor 1995, Tsui 2001, Wentzel 2002, Wu 2005). Five items were used for voice and five for explanation, also adapted from previous studies (Klammer 1997, Leach-LÃ ${ }^{3}$ pez, Stammerjohan \& McNair 2007, Magner, Welker \& Campbell 1995, O'Connor 1995, Tsui 2001, Wu 2005). Common factor analysis was used to refine and identify constructs to be used in testing hypotheses. The method of extraction used was principal axis factor analysis with Varimax rotation (Hair et al. 2006, Tabachnick \& Fidell 2007). The factor analysis confirmed that the underlying latent construct converged as assumed after the deletion of some items due to low factor loadings (less than .60) (see Table 1).

Table 1: Factor analysis

\begin{tabular}{|c|c|c|c|c|c|}
\hline Constructs & Items & Items deleted & KMO & $\begin{array}{l}\text { percentage } \\
\text { explained }\end{array}$ & Cronbach's Alpha \\
\hline Participation & 9 & P1, P8, P9 & 0.895 & $56.026 \%$ & 0.883 \\
\hline Voice & 5 & V5 & 0.803 & $54.309 \%$ & 0.821 \\
\hline Explanation & 5 & 0 & 0.845 & $52 \%$ & 0.845 \\
\hline
\end{tabular}


The target population for this study was Libyan and Anglo-American (USA, Canada, UK, and Australia) companies operating in the Libyan oil sector. The targeted respondents included accountants in budgeting sections and managers of finance departments. Non-accountants were also surveyed including managers from production, sales, purchasing, human resources, training, drill and workover (operations), exploration, and marketing. All Libyan (14) and Anglo-American (12) companies operating in the Libyan oil sector agreed to participate in the research except for two Libyan companies and two Anglo-American companies which declined to participate.

Five hundred survey questionnaires were sent to both Libyan (320) and Anglo-American (180) employees to solicit information from participants who have direct experience in the budgeting process. A total of 372 completed questionnaires (74\%) were received back from Libyan and Anglo-American respondents of which 343 questionnaires $(68 \%)$ were determined as suitable for inclusion in the data set. However, 29 questionnaires were determined to be unsuitable due to being incomplete (greater than $10 \%$ missing data per case) or inconsistent in responses. The surveys received from Libyan companies numbered 250 and 228 questionnaires were deemed useable (71\%). Responses from Anglo-American companies amounted to 122 completed questionnaires. A total of 115 questionnaires were deemed useable $(63 \%)$ and seven were not utilized. The number of questionnaires distributed to Libyan companies was higher than Anglo-American companies because of the higher numbers of staff working for Libyan companies.

T-test and one-way ANOVA were used in this study. T-tests were used to test hypotheses in order to see if there are any differences between the two company group in terms of their budgets and budgeting processes in terms of participation, voice, and explanation. A one-way ANOVA was conducted to look at the differences between: (a) Libyans working in Libyan companies and Anglo-Americans working in Anglo-American companies; (b) Libyans working in Libyan companies and Libyans working in Anglo-American companies; and (c) Libyans working in Anglo-American companies and Anglo-Americans working in Anglo-American companies.

\section{Data Analysis}

In testing Hypothesis 1, a t-test indicates that there is a statistically significant difference between the two company groups in terms of participation in the budgeting process $\left(t{ }_{(328)}=6.176, p=0.001\right)$. As predicted, employees in Anglo-Americans companies had a higher level of participation $(M=3.82, S D=0.68)$ than employees in Libyan companies $((M=3.28, S D=0.78)$. Welch and Brown-Forsythe tests show a significant difference among groups $\left(\mathrm{F}_{(2,327)}=40.123, p=0.001\right)$. Anglo-American employees show the greatest participation in budgeting processes $(\mathrm{M}=4.18, \mathrm{SD}=0.53)$, Libyan employees in Anglo-American companies show lower levels $(\mathrm{M}=3.35, \mathrm{SD}=0.58)$, and Libyan employees in Libyan companies show they have the least participation in the budgeting process $(\mathrm{M}=3.28, \mathrm{SD}=0.79)$. Analysis using Games-Howell post-hoc criterion for significance indicates that there are statistically significant differences between Libyan employees in Libyan companies and AngloAmericans in Anglo-American companies. However, Libyan employees in Libyan companies did not significantly differ from Libyan employees in Anglo-American companies. By contrast, there is a statistically significant difference between Anglo-American and Libyan employees in Anglo-American companies. Therefore, Hypothesis 1 is supported. Anglo-American employees participate much more in the budgeting process than Libyans, whether they work for Anglo-American or Libyan companies. In relation to Hypothesis 2, a t-test indicates that there is a statistically significant difference between the two company groups in terms of their voice or say in the budgeting process $\left(t_{(\mathbf{3 2 8})}=6.919, p=0.001\right)$. As predicted, employees in Anglo-American companies had a greater say in the budgeting process $(M=3.93, S D=0.54)$ than employees in Libyan companies $((M=3.41$, $S D=0.79$ ).

Welch and Brown-Forsythe tests show a statistically significant difference among cultural groups $\left(\mathrm{F}_{(\mathbf{2}, 327)}=\right.$ 33.131, $p=0.001)$. Anglo-American employees have more voice $(\mathrm{M}=4.21, \mathrm{SD}=0.43)$, Libyan employees in Anglo-American companies have less say $(\mathrm{M}=3.56, \mathrm{SD}=0.44)$, and Libyans in Libyan companies have the least voice in the budgeting process $(\mathrm{M}=3.41, \mathrm{SD}=0.79)$. Post hoc analysis using Games-Howell post-hoc criterion for significance indicates that the mean score for Libyans in Libyan companies and Anglo-Americans in AngloAmerican companies were significantly different. However, no significant difference was found between Libyans in Libyan companies and Libyans in Anglo-American companies. By contrast, there is a significant difference between Anglo-Americans and Libyans in Anglo-American companies. Thus Hypothesis 2 is supported for voice in budgeting processes in a similar manner to participation. In relation to Hypothesis 3, "employees in AngloAmerican companies receive more explanation about the changes in their budgets than employees in Libyan companies" a t-test was used. 
The results indicate that there is a statistically significant difference between the two company groups $(t$ (328) $=6.182, p=0.001)$. Employees in Anglo-Americans companies received a higher level of explanation $(M=3.69$, $S D=0.72)$ than those in Libyan companies $((M=3.17, S D=0.73)$. ANOVA analysis shows statistically significant differences among cultural groups $\left(\mathrm{F}_{(\mathbf{2}, 327)}=33.806, p=0.001\right)$. Anglo-Americans receive more explanations about changes in their budgets $(\mathrm{M}=3.99, \mathrm{SD}=0.69)$, Libyans in Anglo-American companies receive less explanation $(\mathrm{M}=3.31, \mathrm{SD}=0.55)$, and Libyans in Libyan companies receive the least explanation $(\mathrm{M}=3.17$, $\mathrm{SD}=0.73$ ). Results from post-hoc comparisons, using Scheffe test because the variances between groups are equal, indicate that there are statically significant differences between Libyans in Libyan companies and AngloAmericans in Anglo-American companies. Results also indicate there is no significant difference between Libyans in Libyan companies and Libyans in Anglo-American companies while there is a significant difference between Anglo-Americans and Libyans in Anglo-American companies. Therefore, Hypothesis 3 is supported in a similar manner to voice and participation.

\section{Conclusion}

These results indicate statistically significant differences between Libyan employees and Anglo-American employees in their participation, voice, and explanation in terms of budgeting processes. In addition, there are slight differences between Libyan participants in Libyan companies and Libyan participants in Anglo-American companies. This is clear evidence that supports the influence of power distance on employees in both company groups which support the notion that societal culture influences employee behaviour. However, participation, voice, and explanation might be greater in the Libyan oil sector than in other sectors. It is important to note that most Libyan oil companies were established by multinational companies or by involvement of multinational companies as financiers, partners, or consultants. Libya was subjected to many colonizers which affected most Libyan business processes including accounting systems (Abouzied 2005). Thus aspects of budgets and budgeting processes were introduced by multinational companies which implied adoption of western accounting systems and practices, most particularly from USA and UK, and these have not changed much since they were implemented (Abouzied 2005). One important question to emerge from these results is to what extent Libyan employees are truly given less voice and participation than Anglo-American employees even in Anglo-American companies and to what extent do they fail to recognize or take advantage of the opportunities that do exist.

It could be argued that culture is entrenched in managerial behaviour. Douglas et al. (2007) identified the differences in behaviour between Egyptian and American employees and argued that their findings support the notion that management behaviour is embedded in culture. The Libyan employees maintain their own culture. They keep their own culture even when working in different companies with different cultures, even when it comes to participation, voice, and explanation in the budgeting process.

This study contributes to the extant literature in terms of budgeting processes, participation, voice and explanation. A review of the literature suggests that no known previous study has attempted to address empirically how culture influences perceptions of the effectiveness of various levels of voice and explanation in the budgeting process (Yee, 2008). The study also helps to fill a gap in empirical studies on cross-cultural differences in budgeting processes comparing Western developed countries (Anglo-American) and non-Western developing countries (North Africa) countries in general and Libya in particular (Atiyyah, 1993; Kozan, 1993). Lastly, the study's results provide further descriptive insights relating to Hofstede's (2005) model of cultural dimensions.

\section{References}

Abouzied, M 2005, International Accounting and its Reflection on Arabic Countries (in Arabic), first edn, Etrak, Cairo.

Al-Hengari, S, El-Bousiffi, M and El-Moudir, W 2007, 'Libyan Petroleum Institute experience in evaluation ofdesalination plants in the Libyan oil sector', Desalination, vol. 206, no. 1-3, 633-52.

Ali, AJ 1990, 'Management Theory in a Transitional Society: the Arab's Experience', International Studies of Management \& Organization, vol. 20, no. 3, 7-35.

Ali, AJ 1993, 'Decision-Making Style, Individualism, and Attitudes Toward Risk of Arab Executives', International Studies of Management \& Organization, vol. 23, no. 3, 53.

Arora, B 1992, 'Participative Management or Managed Participation the Case of India', Economic and Industrial Democracy, vol. 13, 263-72. 
Ashkanasy, NM, Trevor-Roberts, E and Earnshaw, L 2002, 'The Anglo Cluster: legacy of the British empire', Journal of World Business, vol. 37, no. 1, 28-39.

Atiyyah, H 1993, 'Management development in Arab countries: The challenges of the 1990s', Journal of Management Development, vol. 12, no. 1, 3-12.

Aycan, Z 2000, 'Cross-Cultural Industrial and Organizational Psychology: Contributions, Past Developments, and Future Directions', Journal of Cross-Cultural Psychology, vol. 31, no. 1, 110-28.

Bailes, J and Asada, T 1991, 'Empirical differences between Japanese and American budgets and performance evaluation systems ', International Journal of Accounting, vol. 26, no. 2, 131-42.

Ball, DA, McCulloch, WH, Jr., Geringer, JM, Minor, MS and McNett, JM 2008, International business : the challenge of global competition, 11th edn, McGraw-Hill Irwin, Boston London.

Bart, CK 1988, 'Budgeting Gamesmanship', Academy of Management Executive (08963789), vol. 2, no. 4, 285 94.

Baskerville, RF 2003, 'Hofstede never studied culture', Accounting, Organizations and Society, vol. 28, no. 1, 114.

Bies, RJ and Shapiro, DL 1988, 'Voice and Justification: Their Influence on Procedural Fairness Judgments', Academy of Management Journal, vol. 31, no. 3, 676-85.

Bing, JW 2004, 'Hofstede's consequences: The impact of his work on consulting and business practices', Academy of Management Executive, vol. 18, no. 1, 80-7.

Bjerke, B and Al-Meer, A 1993, 'Culture's consequences: Management in Saudi Arabia', Leadership and Organization DevelopmentJournal, vol. 14, no. 2, 30.

Brockner, J and Wiesenfeld, BM 1996, 'An integrative framework for explaining reactions to decisions: Interactive effects of outcomes and procedures', Psychological Bulletin, vol. 120, no. 2, 189-208.

Brockner, J, Ackerman, G, Greenberg, J, Gelfand, MJ, Francesco, AM, Chen, ZX, Leung, K, Bierbrauer, G, Gomez, C, Kirkman, BL and Shapiro, D 2001, 'Culture and Procedural Justice: The Influence of Power Distance on Reactions to Voice', Journal of Experimental Social Psychology, vol. 37, no. 4, 300-15.

Byrne, S and Damon, F 2008, 'To participate or not to participate? Voice and explanation effects on performance in a multi-period budget setting', The British Accounting Review, vol. 40, no. 3, 207-27.

Chapman, M 1996, 'Social Anthropology, Business Studies, and Cultural Issues. (cover story)', International Studies of Management \& Organization, vol. 26, no. 4, 3-29.

Chenhall, RH and Brownell, P 1988, 'The effect of participative budgeting on job satisfaction and performance: Role ambiguity as an intervening variable', Accounting, Organizations and Society, vol. 13, no. 3, 225-33.

Chong, VK and Chong, KM 2002, 'Budget Goal Commitment and Informational Effects of Budget Participation on Performance: A Structural Equation Modeling Approach', Behavioral Research in Accounting, vol. 14, 65.

Christie, PMJ, Kwon, I-WG, Stoeberl, PA and Baumhart, R 2003, 'A Cross-Cultural Comparison of Ethical Attitudes of Business Managers: India Korea and the United States', Journal of Business Ethics, vol. 46, no. 3, 263-87.

Clarke, JI 1963, 'Oil in Libya: Some Implications', Economic Geography, vol. 39, no. 1, 40-59.

Cropanzano, R, Prehar, CA and Chen, PY 2002, 'Using Social Exchange Theory to Distinguish Procedural from Interactional Justice', Group Organization Management, vol. 27, no. 3, 324-51.

Dahl, S 2004, 'Intercultural Research: The Current State of Knowledge', SSRN.

De Cremer, D and Stouten, J 2005, 'When Does Giving Voice or Not Matter? Procedural Fairness Effects as a Function of Closeness of Reference Points', Current Psychology, vol. 24, no. 3, 203-13.

De Cremer, D, Cornelis, I and Van Hiel, A 2008, 'To Whom Does Voice in Groups Matter? Effects of Voice on Affect and Procedural Fairness Judgments as a Function of Social Dominance Orientation', Journal of Social Psychology, vol. 148, no. 1, 61-76.

Detert, JR and Burris, ER 2007, 'Leadership Behavior and Employee Voice: Is The Door Really Open?' Academy of Management Journal, vol. 50, no. 4, 869-84.

DeVellis, R 2003, Scale Development: Theory and Applications, 2 edn, Sage Publications, California.

Douglas, P and Wier, B 2005, 'Cultural and ethical effects in budgeting systems: Acomparison of US and Chinese managers', Journal of Business Ethics, vol. 60, no. 2, 159-74. 
Douglas, P, HassabElnaby, H, Norman, CS and Wier, B 2007, 'An investigation of ethical position and budgeting systems: Egyptian managers in US and Egyptian firms', Journal of International Accounting, Auditing and Taxation, vol. 16, no. 1, 90-109.

Drogendijk, R and Slangen, A 2006, 'Hofstede, Schwartz, or managerial perceptions? The effects of different cultural distance measures on establishment mode choices by multinational enterprises', International Business Review, vol. 15, no. 4, 361-80.

Dundon, T, Wilkinson, A, Marchington, M and Ackers, P 2004, 'The meanings and purpose of employee voice', International Journal of Human Resource Management, vol. 15, no. 6, 1149-70.

Dwyer, S, Mesak, H and Hsu, M 2005, 'An Exploratory Examination of the Influence of National Culture on Cross-National Product Diffusion', Journal of International Marketing, vol. 13, no. 2, 1-27.

Fang, T 2006, 'Asian management research needs more self-confidence', Asia Pacific Journal of Management, vol. 23, no. 2, 119-37.

Fang, T 2009, 'Asian management research needs more self-confidence: Reflection on Hofstede (2007) and beyond', Asia Pacific Journal of Management.

Fidler, F and Thompson, B 2001, 'Computing Correct Confidence Intervals for Anova Fixed-and Random-Effects Effect Sizes', Educational and Psychological Measurement, vol. 61, no. 4, 575-604.

Field, A 2009, Discovering Statistics Using SPSS 3edn, Sage, London.

Frucot, V and Shearon, WT 1991, 'Budgetary participation, locus of control, and Mexican managerial performance and job satisfaction', Accounting Review, vol. 66, no. 1, 80.

Fuller, JB, Barnett, T, Hester, K, Relyea, C and Frey, L 2007, 'An Exploratory Examination of Voice Behavior from an Impression Management Perspective', Journal of Managerial Issues, vol. 19, no. 1, 134-51.

Galang, MC 1999, 'Employee reactions to voice and choice in the workplace: the influence of culture', International Journal of Human Resource Management, vol. 10, no. 4, 703-15.

Garrison, RH, Noreen, EW and Brewer, PC 2006, Managerial accounting, 11th edn, McGraw-Hill/Irwin, Boston.

Greenberg, J 2001, 'Studying Organizational Justice Cross-Culturally: Fundamental Challenges', International Journal of Conflict Management (1997-2002), vol. 12, no. 4, 365.

Griffin, R and Pustay, MW 2010, International business, 6th edn, Prentice Hall, Upper Saddle River.

Gupta, V, Hanges, PJ and Dorfman, P 2002, 'Cultural clusters: methodology and findings', Journal of World Business, vol. 37, no. 1, 11-5.

Gurney, J 1996, Libya: The political economy of oil Energy Policy, Oxford University Press, Oxford.

Hafner, M 2002, 'Future Natural Gas Supply Options and Supply Costs for Europe', Sophia Antipolis.

Hair, J, F., Black, W, C., Babin, B, J., Anderson, R, E. and Tatham, R, L. 2006, Multivariate Data Analysis, 6th edn, Pearson Prentice Hall, Upper Saddle River.

Hampden-Turner, C and Trompenaars, F 1997, 'Response to Geert Hofstede', International Journal of Intercultural Relations, vol. 21, no. 1, 149-59.

Harlos, KP 2001, 'When Organizational Voice Systems Fail: More on the Deaf-Ear Syndrome and Frustration Effects', Journal of Applied Behavioral Science, vol. 37, no. 3, 324-42.

Harris, S and Chris, C 2008, 'National cultural values and the purpose of businesses', International Business Review, vol. 17, no. 1, 103-17.

Harrison, GL 1992, 'The cross-cultural generalizability of the relation between participation, budget emphasis and job related attitudes', Accounting, Organizations and Society, vol. 17, no. 1, 1-15.

Harrison, GL, McKinnon, JL, Panchapakesan, S and Leung, M 1994, 'The Influence of Culture on Organizational Design and Planning and Control in Australia and the United States Compared with Singapore and Hong Kong', Journal of International Financial Management \& Accounting, vol. 5, no. 3, 242-61.

Hofstede, G 1968, The game of budget control, Technology and democratic society, Tavistock; Van Gorcum, London, Assen.

Hofstede, G 1983, 'The Cultural Relativity of Organizational Practices and Theories', Journal of International Business Studies, vol. 14, no. 2, 75-89.

Hofstede, G 2001, Culture's consequences : comparing values, behaviors, institutions, and organizations across nations, 2 edn, Sage Publications, Thousand Oaks.

Hofstede, G and Hofstede, GJ 2005, Cultures and Organizations Software of the Mind, second edn, McGraw-Hill, New York. 
Honold, P 2000, 'Culture and Context: An Empirical Study for the Development of a Framework for the Elicitation of Cultural Influence in Product Usage', International Journal of Human-Computer Interaction, vol. 12 , no. 3/4, 327-45.

Horngren, CT, Foster, G and Datar, SM 1996, Cost accounting : a managerial emphasis, 10th ; annotated instructor's edn, Prentice Hall, Upper Saddle River.

Horngren, CT, Sundem, GL and Stratton, WO 2005, Introduction to management accounting, 13th edn, Pearson Educational, Upper Saddle River.

Horvath, M, Ryan, AM and Stierwalt, SL 2000, 'The Influence of Explanations for Selection Test Use, Outcome Favorability, and Self-Efficacy on Test-Taker Perceptions', Organizational Behavior and Human Decision Processes, vol. 83, no. 2, 310-30.

Jain, HC and Verma, A 1996, 'Managing workforce diversity for competitiveness The Canadian experience', Journal:International Journal of Manpower, vol. 17, no. 4/5, 14 - 29.

Jansen, EP, Merchant, KA and Van der Stede, WA 2009, 'National differences in incentive compensation practices: The differing roles of financial performance measurement in the United States and the Netherlands', Accounting, Organizations and Society, vol. 34, no. 1, 58-84.

Kabasakal, H and Bodur, M 2002, 'Arabic cluster: a bridge between East and West', Journal of World Business, vol. 37, no. 1, 40-54.

Kerlinger, F and Lee, H 2000, Foundations of Behavioural Reseach, 4th edn, Harcourt, Inc, Philadelphia.

Kim, T-Y and Leung, K 2007, 'Forming and reacting to overall fairness: A cross-cultural comparison', Organizational Behavior and Human Decision Processes, vol. 104, no. 1, 83-95.

Klammer, JD 1997, Speaking Up In The Workplace: Modeling The Implications of Procedural Justice, Perceived Organizational Support, Being Heard, and Tokensm In The Relationship Between Voice and Civic Virtue, Master Thesis thesis, The University of Calgary.

Lau, CM and Tan, JJ 1998, 'The impact of budget emphasis, participation and task difficulty on managerial performance: a cross-cultural study of the financial services sector', Management Accounting Research, vol. 9, no. 2, 163-83.

Lau, CM and Buckland, C 2000, 'Budget emphasis, participation, task difficulty and performance: the effect of diversity within culture', Accounting \& Business Research, vol. 31, no. 1, 37-55.

Leach-LÃ $\tilde{p}^{\mathrm{pez}}$, MA, Stammerjohan, WW and McNair, FM 2007, 'Differences in the Role of Job-Relevant Information in the Budget Participation-Performance Relationship among U.S. and Mexican Managers: A Question of Culture or Communication', Journal of Management Accounting Research, vol. 19, 105-36.

Leedy, PD and Ormrod, JE 2005, Practical Research: Planning and Design, 8th edn, Pearson/Merrill Prentice Hall, Upper Saddle River.

Libby, T 1999, 'The influence of voice and explanation on performance in a participative budgeting setting', Accounting, Organizations and Society, vol. 24, no. 2, 125-37.

Libby, T 2001, 'Referent Cognitions and Budgetary Fairness: A Research Note', Journal of Management Accounting Research, vol. 13, 91-105.

Licata, MP, Strawser, RH and Welker, RB 1986, 'A Note on Participation in Budgeting and Locus of Control', Accounting Review, vol. 61, no. 1, 112.

Lind, EA, Kanfer, R and Earley, PC 1990, 'Voice, Control, and Procedural Justice: Instrumental and Noninstrumental Concerns in Fairness Judgments', Journal of Personality \& Social Psychology, vol. 59, no. $5,952-9$.

Lindquist, TM 1995, 'Fairness as an Antecedent to Participative Budgeting: Examining the Effects of Distributive Justice, Procedural Justice and Referent Cognitions on Satisfaction and Performance', Journal of Management Accounting Research, vol. 7, 122-47.

Magner, N, Welker, RB and Campbell, TL 1995, 'The interactive effect of budgetary participation and budget favorability on attitudes toward budgetary decision makers: A research note', Accounting, Organizations and Society, vol. 20, no. 7-8, 611-8.

Magner, N, Johnson, G, Little, H, Staley, A and Welker, R 2006, 'The case for fair budgetary procedures', Managerial Auditing Journal, vol. 21, no. 4, 408-19.

Maiga, AS and Jacobs, FA 2007, 'The moderating effect of manager's ethical judgment on the relationship between budget participation and budget slack', Advances in Accounting, vol. 23, 113-45. 
McSweeney, B 2002a, 'The essentials of scholarship: A reply to Geert Hofstede', Human Relations, vol. 55, no. $11,1363-72$.

McSweeney, B 2002b, 'Hofstede's Model of National Cultural Differences and their Consequences: A Triumph of Faith - a Failure of Analysis', Human Relations, vol. 55, no. 1, 89-118.

Mendonca, M and Kanungo, RN 1996, 'Impact of Culture on Performance Management in Developing Countries', International Journal of Manpower, vol. 17, no. 4/5, pp. 65-75.

Merchant, KA, Chow, CW and Wu, A 1995, 'Measurement, evaluation and reward of profit center managers: A cross-cultural field study', Accounting, Organizations and Society, vol. 20, no. 7-8, 619-38.

Mickey, RM, Dunn, OJ and Clark, VA 2004, Applied Statistics Analysis of Variance and Regression, 3th edn, John Wiley \& Sons, New Jersey.

Milani, K 1975, 'The Relationship of Participation in Budget-Setting to Industrial Supervisor Performance and Attitudes: A Field Study', Accounting Review, vol. 50, no. 2, 274.

Miroshnik, V 2002, 'Culture and international management: a review', Journal of Management Development, vol. 21, no. 7, 521-44.

Mowen, MM and Hansen, DR 2006, Management accounting : the cornerstone for business decisions, 1st edn, Thomson/South-Western, Mason Southbank.

O'Brien, RG 1979, 'A General ANOVA Method for Robust Tests of Additive Models for Variances', Journal of the American Statistical Association, vol. 74, no. 368, 877-80.

O'Connor, NG 1995, 'The influence of organizational culture on the usefulness of budget participation by Singaporean-Chinese managers', Accounting, Organizations and Society, vol. 20, no. 5, 383-403.

Osland, JS and Bird, A 2000, 'Beyond sophisticated stereotyping: Cultural sensemaking in context', Academy of Management Executive, vol. 14, no. 1, 65-77.

Paláu, SL 2001, 'Ethical evaluations, intentions, and orientations of accountants: Evidence from a cross-cultural examination', International Advances in Economic Research, vol. 7, no. 3, 351-64.

Pasewark, WR and Welker, RB 1990, 'A Vroom-Yetton Evaluation of Subordinate Participation in Budgetary Decision Making', Journal of Management Accounting Research, vol. 2, 113.

Prabhu, NRV 2005, 'Cultural Influence on Managerial Thinking', Journal of Management Research (09725814), vol. 5, no. 3, 113-28.

Radebaugh, L, Gray, SJ and Arpan, JS 1997, International accounting and multinational enterprises, 4th edn, Wiley, New York.

Radebaugh, L, Gray, SJ and Black, EL 2006, International accounting and multinational enterprises, 6th edn, John Wiley \& Sons, Hoboken.

Renard, M and Eastwood, K 2003, 'Cultural Masks: Giving Voice to The Margins', Administrative Theory \& Praxis (Administrative Theory \& Praxis), vol. 25, no. 4, 499-512.

Robbins, SP, Judge, TA, Millet, B and Waters-Marsh, T 2008, Organisational behaviour, 5th edn, Pearson Education Australia, Frenchs Forest.

Ronen, S and Shenkar, O 1985, 'Clustering Countries on Attitudinal Dimensions: A Review and Synthesis', Academy of Management Review, vol. 10, no. 3, 435-54.

Sauers, DA, Lin, SCH, Kennedy, J and Schrenkler, J 2009, 'A comparison of the performance appraisal practices of US multinational subsidiaries with parent company and local Taiwanese practices', Journal:Management Research News, vol. 32, no. 3, 286 - 96.

Schwartz, S, H 1994, Beyond Individualism/Collectivism New Cultural Dimensions Of Values, in U Kim, HC Triandis, K Cigdem, C Sang-Chin and Y Gene (eds), Individualism and collectivism : theory, method, and applications, Sage Publications, Thousand Oaks, 85-119.

Sengupta, SS and Sinha, JBP 2005, 'Perceived Dimensions of Societal and Organizational Cultures and their Impact on Managerial Work Behavior', Journal of Management Research (09725814), vol. 5, no. 3, 143 72.

Shields, JF and Shields, MD 1998, 'Antecedents of participative budgeting', Accounting, Organizations and Society, vol. 23, no. 1, 49-76.

Silvia, L 2006, Culture Effects In The Ethical Decision-Making Process of Latin Amercan Accountants, PhD thesis, Texas-Pan America.

Skarlicki, DP 2001, 'Cross-Cultural Perspective of Organizational Justice', International Journal of Conflict Management (1997-2002), vol. 12, no. 4, 292. 
Skarlicki, DP and Folger, R 1997, 'Retaliation in the Workplace: The Roles of Distributive, Procedural, and Interactional Justice', JOURNAL OF APPLIED PSYCHOLOGY, vol. 82, 434-43.

Smith, PB 2002, 'Culture's Consequences: Something Old and Something New', Human Relations, vol. 55, no. 1, 119-35.

Soares, AM, Farhangmehr, M and Shoham, A 2007, 'Hofstede's dimensions of culture in international marketing studies', Journal of Business Research, vol. 60, no. 3, 277-84.

Sondergaard, M 1994, 'Research Note: Hofstede's Consequences: A Study of Reviews, Citations and Replications', Organization Studies, vol. 15, no. 3, 447-56.

Tabachnick, BG and Fidell, LS 2007, Using Multivariate Statistics, 5 edn, Allyn and Bacon, Boston, MA.

Tangirala, S and Ramanujam, R 2008, 'Exploring Nonlinearity In Employee Voice: The Effects of Personal Control and Organizational Indentification', Academy of Management Journal, vol. 51, no. 6, 1189-203.

Tata, J 2005, 'The Influence of National Culture on the Perceived Fairness of Grading Procedures: A Comparison of the United States and China', Journal of Psychology, vol. 139, no. 5, 401-12.

Tayeb, M 1997, 'Islamic revival in Asia and human resource management', Employee Relations, vol. 19, no. 4, 352-64.

Taylor, M 2000, 'Cultural variance as a challenge to global public relations: A case study of the Coca-Cola scare in Europe', Public Relations Review, vol. 26, no. 3, 277-93.

Tsui, JSL 2001, 'The impact of culture on the relationship between budgetary participation, management accounting systems, and managerial performance: An analysis of Chinese and Western managers', The International Journal of Accounting, vol. 36, no. 2, 125-46.

Twati, JM 2007, Societal and Organisational Culture and The Adoption of Management Information Systems in Arab Countries PhD thesis, Griffith University.

Ueno, S and Sekaran, U 1992, 'The influence of culture on budget control practices in the USA and Japan: An empirical study', Journal of International Business Studies, vol. 23, no. 4.

Ueno, S and Wu, FH 1993, 'The comparative influence of culture on budget control practices in the United States and Japan', International Journal of Accounting, vol. 28, no. 1, 17-39.

Vallejo, G and Ato, M 2006, 'Modified Brown-Forsythe Procedure for Testing Interaction Effects in Split-Plot Designs', Multivariate Behavioral Research, vol. 41, no. 4, 549 - 78.

Van Dyne, L, Soon, A and Botero, IC 2003, 'Conceptualizing Employee Silence and Employee Voice as Multidimensional Constructs', Journal of Management Studies, vol. 40, no. 6, 1359-92.

Weber, M 1965, The Protestant Ethic and the Spirit of Capitalism, New York, NY: Unwin Univ, Parsons (trans)

Weijermars, R, de Jong, V and van der Kooi, K 2008, 'Cultural challenges in oil and gas industry management', World Oil, vol. 229, no. 4, 49-76.

Wentzel, K 2002, 'The Influence of Fairness Perceptions and Goal Commitment on Managers' Performance in a Budget Setting', Behavioral Research in Accounting, vol. 14, 247.

Weygandt, JJ, Kimmel, PD and Kieso, DE 2001, Managerial accounting : tools for business decision making, 2nd edn, Wiley, New York.

Williamson, D 2002, 'Forward from a Critique of Hofstede's Model of National Culture', Human Relations, vol. 55 , no. $11,1373-95$.

Wu, EC 2005, 'Convergence of Attitudes in Different Cultures Towards the Budgeting Process', Journal of Business \& Management, vol. 11, no. 2, 29-47.

Yasin, MM and Stahl, MJ 1990, 'An Investigation of Managerial Motivational Effectiveness in the Arab Culture', International Studies of Management \& Organization, vol. 20, no. 3, 69-78.

Yates, G and Cutler, B 1996, 'Hofstede's model of national culture: A social science contribution to international business', Journal of Teaching in International Business, vol. 8, 77-93.

Yee, C, Setsuo, O, Kieran, J and Kwai-Sim, LJ 2008, 'Japanese culture and budgeting: a review of the literature and a limited pilot study to illustrate the research agenda', Managerial Auditing Journal, vol. 23, no. 9, 873-99.

Zaharna, RS 1995, 'Understanding cultural preferences of Arab communication patterns', Public Relations Review, vol. 21 , no. 3, 241-55.

Zikmund, W 2000, Business Research Methods, 6th edn, Harcourt College Publishers. 


\section{Appendix A}

Section A: Information about the budget: Here are some statements that describe how employees might feel about budgeting and budgets in their organization. Please tick $(\sqrt{ })$ on the spaces that indicate the degree to which you agree or disagree with each statement.

\begin{tabular}{|c|c|c|c|c|c|}
\hline Participation & 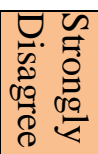 & 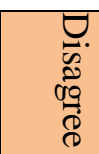 & 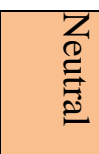 & 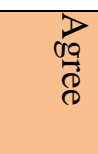 & 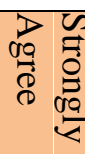 \\
\hline $\begin{array}{l}\text { 1. I am involved in setting all portions of the budget for my } \\
\text { unit. }\end{array}$ & $(\quad)$ & $($ ) & $($ ) & $($ ) & $($ ) \\
\hline 2. My contribution to the budget is very important. & $($ ( ) & $($ ( ) & $($ ) & () & $($ ) \\
\hline 3. My budget is finalized only when I am satisfied with it. & () & $($ ) & () & () & () \\
\hline $\begin{array}{l}\text { 4. My supervisors seek my opinions and/or suggestions when } \\
\text { the budget is being formulated. }\end{array}$ & $(\quad)$ & ( ) & ( ) & $(\quad)$ & ( ) \\
\hline $\begin{array}{l}5 . \quad \text { I frequently initiate budget-related discussions with my } \\
\text { superior. }\end{array}$ & $($ ) & $($ ) & $($ ) & $($ ) & $($ ) \\
\hline 6. $\quad$ The revised budget includes changes I have suggested. & $($ ) & $($ ) & $($ ) & () & $($ ( ) \\
\hline $\begin{array}{l}\text { 7. My input to budget formulation influences my superiors in } \\
\text { their final decisions on the budget. }\end{array}$ & ( ) & $($ ) & ( ) & $($ ) & $($ ) \\
\hline $\begin{array}{l}\text { 8. I prepare my budget according to top management's } \\
\text { instructions. }\end{array}$ & ( ) & $($ ( ) & $($ ) & $(\quad)$ & $($ ) \\
\hline $\begin{array}{l}\text { I. have formal meetings with people from other units when } \\
\text { budget is being prepared. }\end{array}$ & $(\quad)$ & $(）$ & $(\quad)$ & $(\quad)$ & $($ ) \\
\hline \multicolumn{6}{|l|}{ Voice } \\
\hline $\begin{array}{l}\text { 1. My superior's behavior tells me that he/she listens to what I } \\
\text { have to say about the budget. }\end{array}$ & $(\quad)$ & ( ) & $($ ) & $(\mathbf{~ ) ~}$ & $(\quad)$ \\
\hline $\begin{array}{l}\text { 2. My company has procedures available that allow me to } \\
\text { make suggestions for improvement to the budget process. }\end{array}$ & $($ ) & $(\quad)$ & $($ ) & $(\quad)$ & $($ ) \\
\hline $\begin{array}{l}\text { 3. I have constructive discussions related to the budget } \\
\text { process with my superior and co-workers. }\end{array}$ & $($ ) & $($ ) & $($ ) & $($ ) & $($ ) \\
\hline $\begin{array}{l}\text { 4. I usually state my requests, opinions, and/or suggestions } \\
\text { about the budget to my superior without being asked. }\end{array}$ & $($ ) & $($ ( ) & ( ) & $($ ) & $($ ) \\
\hline 5. I offer suggestions for the improvement of budget systems. & () & $(\mathbf{)}$ & () & $(\quad)$ & $(\mathbf{)}$ \\
\hline \multicolumn{6}{|l|}{ Explanation } \\
\hline $\begin{array}{l}\text { 1. The reasoning provided by my superior when budget revisions } \\
\text { are made is very sound and logical. }\end{array}$ & $($ ) & $($ ) & $($ ) & $(\quad)$ & $($ ( ) \\
\hline $\begin{array}{l}\text { 2. My superior provides me with an explanation for changes in the } \\
\text { budget. }\end{array}$ & $($ ) & $($ ) & $($ ) & $($ ) & $($ ) \\
\hline $\begin{array}{l}\text { 3. I receive written or/and oral reports explaining why the budget } \\
\text { does not reflect my suggestions. }\end{array}$ & $(\quad)$ & $(\quad)$ & $(\quad)$ & $($ ) & ( ) \\
\hline $\begin{array}{l}\text { 4. My superior provides me with timely feedback about decisions } \\
\text { on my budget and their implications. }\end{array}$ & ( ) & ( ) & ( ) & ( ) & ( ) \\
\hline $\begin{array}{l}\text { 5. My superior keeps me fully and frankly informed about } \\
\text { anything related to my budget. }\end{array}$ & $($ ) & ( ) & $($ ( ) & $($ ) & ( ) \\
\hline
\end{tabular}

Section B: Personal and organizational information: The following questions seek general information about you and your organization. Please provide your response by ticking or writing as appropriate.

\begin{tabular}{|l|l|l|}
\hline 1) What is your gender? & Male (...) & Female (...) \\
\hline
\end{tabular}

\begin{tabular}{|l|l|l|l|l|l|l|l|}
\hline $\begin{array}{l}\text { 2) What is } \\
\text { nationality }\end{array}$ & your & Libyan & American & Canadian & UK & Australian & Other ..................specify \\
\hline
\end{tabular}




\begin{tabular}{|l|l|l|l|l|l|l|}
\hline $\begin{array}{l}3) \\
\text { age? }\end{array}$ & What is your & 1 & 2 & 3 & 4 & 5 \\
\cline { 3 - 7 } & & less than 20 years & $21-30$ & $31-40$ & $41-50$ & Over 50 \\
\hline
\end{tabular}

4) What is the nationality (home-country) of the company you are working for (head office)?

\begin{tabular}{|l|l|l|l|l|}
\hline Libyan & American & Canadian & English & Australian \\
\hline
\end{tabular}

\begin{tabular}{|l|l|l|l|l|l|l|}
\hline $\begin{array}{l}\text { What is the level of your } \\
\text { English skills? }\end{array}$ & None & Poor & Average & Good & Fluent \\
\hline
\end{tabular}

6) Which best describes the main operation of your company?

\begin{tabular}{|c|c|c|c|}
\hline Exploration & Refinery & Marketing & 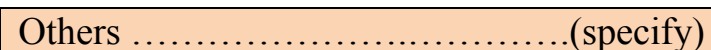 \\
\hline
\end{tabular}

7) What is your level of education?

\begin{tabular}{|l|l|l|l|l|}
\hline 1 & 2 & 3 & 4 & 5 \\
\hline Primary school & High school & Diploma Level & Bachelor degree & Postgraduate level \\
\hline
\end{tabular}

8) How long have you been working within this organization?

\begin{tabular}{|l|l|l|l|l|}
\hline $\mathbf{1}$ & $\mathbf{2}$ & $\mathbf{3}$ & $\mathbf{4}$ & $\mathbf{5}$ \\
\hline $\mathbf{1}-\mathbf{5}$ & $6-10$ & $11-15$ & $16-20$ & Over 20 years \\
\hline
\end{tabular}

9) What position do you hold in this Please specify... company?

10) How long have you been working in this position?

\begin{tabular}{|l|l|l|l|l|}
\hline 1 & 2 & 3 & 4 & 5 \\
\hline $1-5$ years & $6-10$ years & $11-15$ years & $16-20$ years & Over 20 years \\
\hline
\end{tabular}

11) Have you worked in this industry in a country others than Libya? No (...). Yes (...) if yes for how long?

\begin{tabular}{|l|l|l|l|l|l|}
\hline 1 & 2 & 3 & 4 & 5 & 6 \\
\hline Less than 1 & $1-2$ & $2-3$ & $3-4$ & $4-5$ & Over 5 years \\
\hline
\end{tabular}

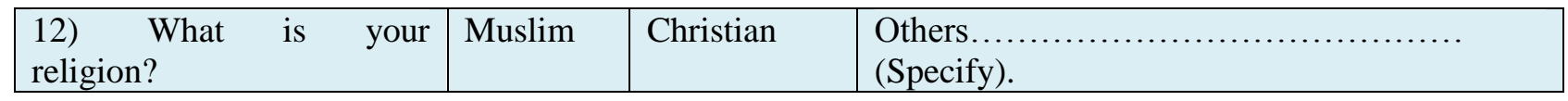

I highly appreciate your contribution to this research by completing the questionnaire. If you have any further comments that may help the researcher draw conclusions to this study please feel free to write your thoughts here: 